\title{
Soil Carbon Sequestrations in Forest Soils in Relation to Parent Material and Soil Depth in South-Eastern Nigeria
}

\section{Chinonso Millicent Chris-Emenyonu ${ }^{1}$, Emmanuel Uzoma Onweremadu', John Didacus Njoku², Chioma Mildred Ahukaemere ${ }^{1}$, Benarden Ngozi Aririguzo ${ }^{1}$}

\author{
${ }^{1}$ Department of Soil Science and Technology, Federal University of Technology, Owerri, Nigeria \\ ${ }^{2}$ Department of Environmental Management, Federal University of Technology, Owerri, Nigeria \\ Email: ^Pricessm2@yahoo.com, *chinonso.chris-emenyonu@futo.edu.ng
}

How to cite this paper: Chris-Emenyonu, C. M., Onweremadu, E. U., Njoku, J. D., Ahukaemere, C. M., \& Aririguzo, B. N. (2020). Soil Carbon Sequestrations in Forest Soils in Relation to Parent Material and Soil Depth in South-Eastern Nigeria. American Journal of Climate Change, 9, 400-409. https://doi.org/10.4236/ajcc.2020.94025

Received: April 27, 2020

Accepted: December 4, 2020

Published: December 7, 2020

Copyright $\odot 2020$ by author(s) and Scientific Research Publishing Inc. This work is licensed under the Creative Commons Attribution International License (CC BY 4.0).

http://creativecommons.org/licenses/by/4.0/

\begin{abstract}
There has been increased interest in soil organic carbon in recent times because of its role in carbon sequestration. Different parent materials affect soil properties and hence will influence how much carbon is sequestered by soil. The study was conducted in June 2019 to investigate soil carbon stock in forest soils with respect to their parent materials in three States in South-eastern Nigeria. Sampling was aided by the location map of the area and free soil survey method was used to locate sampling points. One profile was dug in each location and described using the Food and Agricultural Organization guideline. A total of twelve soil samples were collected and analyzed for selected properties. Results showed that sand content was significantly higher in soils under coastal plain sands $\left(851.96 \mathrm{~g} \cdot \mathrm{kg}^{-1}\right)$ and was lowest in soils of Imo clay shale $\left(605.60 \mathrm{~g} \cdot \mathrm{kg}^{-1}\right)$. Clay content was higher in soils of Imo clay shale $\left(277.34 \mathrm{~g} \cdot \mathrm{kg}^{-1}\right)$ and was lowest in coastal plain sand $\left(118.80 \mathrm{~g} \cdot \mathrm{kg}^{-1}\right)$. Silt and clay had moderate variation in coastal plain sand $(>15 \leq 35 \%)$ and high variations in Asu River and Imo clay shale (CV $>35 \%)$. The soils studied were generally acidic with values ranging (3.52) in soils formed from coastal plain sand, followed by forest soils of Imo clay shale (3.64) and Asu river group (3.85). Soil organic carbon decreased with increase in soil depth in all soil parent materials studied. Mean values ranged from $6.14 \mathrm{~g} \cdot \mathrm{kg}^{-1}$ in soil underlain by coastal plain sand to $10.62 \mathrm{~g} \cdot \mathrm{kg}^{-1}$ ) in soils of Imo clay shale. Soil carbon sequestered under the three different parent materials ranged from $1575-4676.41\left(\mathrm{~g} \cdot \mathrm{cm}^{-2}\right)$. Also, soil depth had a notable impact on carbon sequestration with values ranging from $1529.42-4374.0541\left(\mathrm{~g} \cdot \mathrm{cm}^{-2}\right)$ and the thicker the horizon, the more carbon sequestered. Hence, the study concluded that more carbon is sequestered in the subsurface horizons of the soil pedons than in the epipedons.
\end{abstract}




\section{Keywords}

Carbon Sequestration, Forest, Soils, Parent material, Soil Depth

\section{Introduction}

Currently, some parts of the world are experiencing shortage of food due to climate change impacts (Aticho, 2013) and the rate of soil carbon decline in tropical soils is alarming because soil carbon is a principal factor in measuring the overall quality of a biome. Soil is an essential organic carbon reservoir and play important role in the global carbon cycle. Soil also acts as a sink for carbon dioxide in exchange with the atmosphere in terrestrial ecosystems. According to Alexander et al. (2015), more than $60 \%$ of soil carbon in the world is held in the soil (more than 40\%) and the atmosphere (as carbon dioxide; 20\%). Forest ecosystems store more than $80 \%$ of all terrestrial above-ground carbon and more than $70 \%$ of soil organic carbon (Batjes, 1996). Ahukaemere (2015) reported that conversion of native ecosystems like forests, wetlands and grasslands to agricultural uses, and continuous harvesting of plant materials caused significant losses of plant biomass and carbon, thereby increasing the carbon dioxide $\left(\mathrm{CO}_{2}\right)$ level in the atmosphere. Resck et al. (2008) observed that the use of native forests for cultivation is usually followed by a decline in organic carbon and soil structure deterioration.

Carbon sequestration means the process by which atmospheric $\mathrm{CO}_{2}$ is transferred into the soil through crop remains and other organic solids and stored securely without being re-emitted into the atmosphere for prolonged periods (Lal, 2004). The soil organic carbon pool (SOC) includes highly active humus and relatively inert charcoal C, while the soil inorganic pool (SIC) includes elemental $\mathrm{C}$ and minerals such as calcite, dolomites and gypsum, and are made up of primary and secondary carbonates (Lal, 2004). These primary carbonates are derived from the weathering of parent materials. Scientists are earnestly researching means to stabilize the atmospheric abundance of $\mathrm{CO}_{2}$ and other greenhouse gases to mitigate the risk associated with global warming and this includes means to increase the amount of carbon sequestered in the soil. Sequestration of atmospheric carbon $\left(\mathrm{CO}_{2}\right)$ in the soil helps to offset greenhouse gas emissions, like carbon dioxide emitted by cars, power plants, and other burning of fossil fuels. In fact, the soil has significant potential to store carbon (Batjes, 1996) and to mitigate the effects of climate change.

Since primary carbonates, which are parts of the soil inorganic carbon pool are derived from the weathering of parent materials, a good understanding of parent materials and their effect on soil organic carbon is necessary to enhance carbon sequestration in order to mitigate climate change. Researches investigating the impact of parent material on carbon sequestration in Nigeria are limited. Hence, this study aimed to assess the effect of different parent materials in fo- 
rested soils on carbon sequestration in South-eastern Nigeria.

\section{Materials and Method}

The study was conducted in Akwette in Abia State, Okigwe in Imo State and Amaeze in Ebonyi State, Southeastern Nigeria in June, 2019. Soils of these areas are formed over coastal plain sands (Benin Formation), Imo clay shale and Asu river group. The study area has a humid tropical climate with a mean annual rainfall range of $1800-2500 \mathrm{~mm}$ and $26^{\circ} \mathrm{C}-31^{\circ} \mathrm{C}$ mean annual temperature range (NIMET, 2019). Soils of these areas generally lie under a depleted rainforest. Low-input agriculture and sand mining are common socio-economic activities of these areas. Random soil survey technique was used and field sampling was guided by the location map of the areas (Figure 1). One profile pit was dug

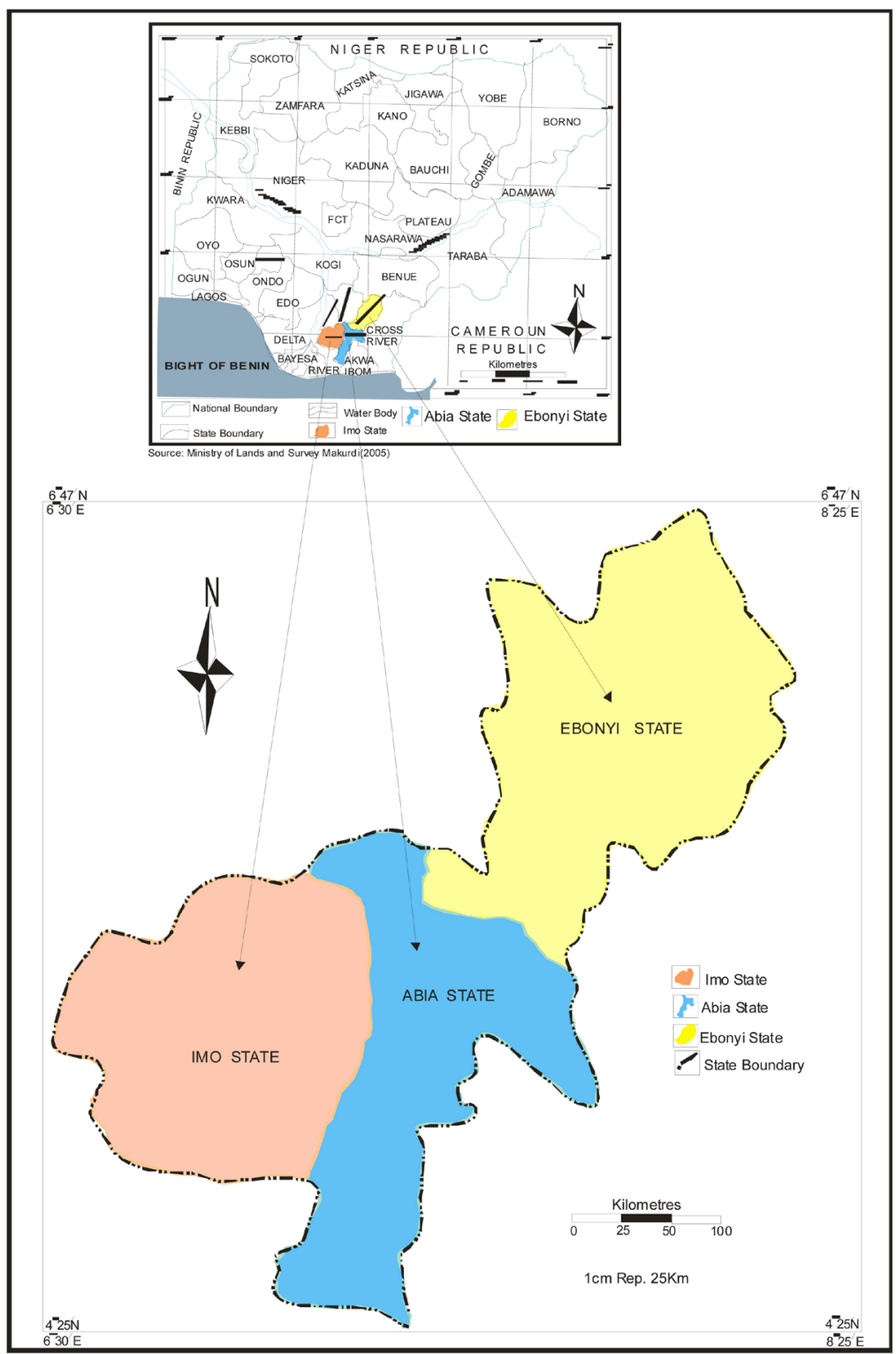

Figure 1. Map of Nigeria showing studied southeastern states. 
in each State and twelve soil samples were collected in total based on horizon differentiation following (FAO, 2006) guidelines. Bulked soil samples collected were air-dried, gently crushed and passed through a 2-mm sieve to obtain fine earth separates. The processed soil samples were analyzed for some physical and chemical properties. Particle size distribution was done by hydrometer method (Gee and Or, 2002), bulk density was done by core method (Grossman and Reinsch, 2002), soil pH was done using pH meter (Hendershot et al., 1993), organic carbon was carried out using wet digestion (Nelson and Sommers, 1996). CEC was determined using the neutral ammonium acetate method. Percentage base saturation was calculated using the formula

$$
\% \mathrm{BS}=\frac{\mathrm{TEB}}{\mathrm{ECEC}} \times 100
$$

where $\%$ BS = Percentage Base Saturation;

$\mathrm{TEB}=$ Total Exchangeable Base;

ECEC = Effective Cation Exchange Capacity.

Carbon stored $\left(\mathrm{g} \mathrm{C} \mathrm{m}^{-2}\right)$ in each horizon was determined by multiplying bulk density $\left(\mathrm{g} \cdot \mathrm{cm}^{-3}\right) \times$ organic carbon $\left(\mathrm{g} \cdot \mathrm{kg}^{-1}\right) \times$ horizon depth $(\mathrm{cm})$ (Batjes, 1996). Carbon storage-horizon depth ratio was obtained by dividing carbon stored in each horizon by the corresponding horizon depth.

Coefficient of variation analysis was used to estimate vertical variations of soil properties and ranking was done using the procedure of Wilding (1985). SAS (2016) software was used for statistical analyses. Properties with larger CV values are more variable than those with smaller CV values. Wilding (1985) described a classification scheme for identifying the extent of variability for soil properties based on the values of their CV, in which CV values of $0-15,16-35$ and $>36 \%$ indicate low (least), moderate and high variability, respectively.

\section{Results and Discussion}

\subsection{Physical and Chemical Properties of Forest Soils}

The physical and chemical properties of the forest soils studied are shown on Table 1. The mean sand, silt and clay contents of the soils ranged from 605.6 $852.96 \mathrm{~g} \cdot \mathrm{kg}^{-1} ; 18.2-57.2 \mathrm{~g} \cdot \mathrm{kg}^{-1}$ and $92.6-122.6 \mathrm{~g} \cdot \mathrm{kg}^{-1}$ respectively. Sand content was highest in soils derived from coastal parent material and values obtained were similar to the findings of Chris-Emenyonu et al. (2019). Sand content had low variation in coastal plain sand $(<15 \%)$ and moderate variation in Imo clay shale and Asu river group ( $>15 \leq 35 \%)$. Silt and clay had moderate variation $(>15 \leq 35 \%)$ in coastal plain sand and high variations in Asu river and Imo clay shale (>36\%). Bulk density differed in respect to parent materials studied and increased down the profile pits with mean values ranging from 1.14 in soils of coastal plain sand to $1.40 \mathrm{~g} \cdot \mathrm{cm}^{-3}$ in soils derived from Asu river group. Bulk density had low variation $(<15 \%)$ irrespective of parent material. The values fall within the range that is expected of tropical soils (Landon, 1991). The soils studied were generally strongly acidic with values ranging from strongly acidic 
Table 1. Physical and chemical characteristics of the forest soils.

\begin{tabular}{|c|c|c|c|c|c|c|c|c|c|c|c|c|c|}
\hline Horizon & $\begin{array}{l}\text { Depth } \\
(\mathrm{cm})\end{array}$ & $\begin{array}{l}\text { Sand } \\
\mathrm{g} \cdot \mathrm{kg}^{-1}\end{array}$ & $\begin{array}{c}\text { Silt } \\
\mathrm{g} \cdot \mathrm{kg}^{-1}\end{array}$ & $\begin{array}{l}\text { Clay } \\
\mathrm{g} \cdot \mathrm{kg}^{-1}\end{array}$ & $\begin{array}{c}\mathrm{BD} \\
\mathrm{g} \cdot \mathrm{cm}^{-3}\end{array}$ & $\begin{array}{l}\text { MC } \\
(\%)\end{array}$ & $\begin{array}{l}\mathrm{pH} \\
\mathrm{KCl}\end{array}$ & $\begin{array}{c}\mathrm{OC} \\
\mathrm{g} \cdot \mathrm{kg}^{-1}\end{array}$ & $\begin{array}{c}\text { AVP } \\
\mathrm{mg} \cdot \mathrm{kg}^{-1}\end{array}$ & $\begin{array}{c}\text { TEB } \\
\mathrm{cmol} / \\
\mathrm{kg}\end{array}$ & $\begin{array}{c}\text { TEA } \\
\mathrm{cmol} / \\
\mathrm{kg}\end{array}$ & $\begin{array}{c}\text { ACEC } \\
\mathrm{cmol} / \\
\mathrm{kg}\end{array}$ & $\begin{array}{l}\text { BS } \\
(\%)\end{array}$ \\
\hline \multicolumn{14}{|l|}{$\begin{array}{l}\text { Coastal } \\
\text { plain }\end{array}$} \\
\hline $\mathrm{A}$ & $0-22$ & 870.2 & 29 & 100.8 & 1.00 & 61.2 & 4.21 & 6.97 & 10.2 & 5.13 & 1.21 & 12.25 & 82.34 \\
\hline $\mathrm{AB}$ & $22-44$ & 869.6 & 32.8 & 97.6 & 1.01 & 72 & 4.16 & 6.73 & 7.50 & 4.26 & 0.35 & 8.36 & 92.4 \\
\hline Bt1 & $44-72$ & 849.6 & 12.8 & 137.6 & 1.18 & 74.75 & 4.11 & 5.92 & 7.66 & 4.57 & 0.34 & 8.82 & 93.08 \\
\hline Bt2 & $72-100$ & 820.8 & 39 & 140.2 & 1.24 & 66.06 & 4.32 & 5.72 & 5.30 & 3.07 & 0.39 & 4.40 & 88.7 \\
\hline $\mathrm{Bt} 3$ & $100-180$ & 849.6 & 32.8 & 117.6 & 1.28 & 51.70 & 4.22 & 5.34 & 6.70 & 3.05 & 0.28 & 4.25 & 91.6 \\
\hline MEAN & & 851.96 & 29.28 & 118.8 & 1.14 & 65.14 & 4.20 & 6.14 & 7.47 & 4.02 & 0.51 & 7.62 & 89.62 \\
\hline SD & & 20.16 & 9.89 & 19.91 & 0.1301 & 9.17 & 0.078 & 0.69 & 1.79 & 0.93 & 0.391 & 3.35 & 4.401 \\
\hline CV\% & & $2.37^{*}$ & $33.74^{* *}$ & $16.76^{* *}$ & $11.40^{*}$ & $14.08^{*}$ & $1.86^{*}$ & $11.24^{*}$ & $23.93^{* *}$ & $23.08^{* *}$ & $76.08^{* * *}$ & $44.11^{* * *}$ & $4.91^{*}$ \\
\hline \multicolumn{14}{|l|}{$\begin{array}{c}\text { Imo } \\
\text { clay shale }\end{array}$} \\
\hline A & $0-19$ & 629.6 & 192.8 & 177.6 & 1.13 & 51.8 & 3.86 & 15.20 & 16.6 & 4.7 & 1.54 & 12.21 & 73.32 \\
\hline $\mathrm{AB}$ & $19-42$ & 549.6 & 312.8 & 137.6 & 1.18 & 50 & 4.00 & 12.80 & 13.5 & 2.71 & 1.5 & 8.62 & 64.37 \\
\hline Bt1 & $42-82$ & 529.6 & 112.8 & 357 & 1.24 & 51.48 & 4.44 & 9.20 & 10.8 & 4.82 & 2.08 & 12.98 & 69.85 \\
\hline Bt2 & $82-133$ & 769.6 & 12.8 & 217.6 & 1.26 & 33.24 & 4.03 & 8.60 & 8.6 & 2.82 & 2.00 & 8.84 & 58.51 \\
\hline $\mathrm{Bt} 3$ & $133-180$ & 549.6 & 232.8 & 217.6 & 1.35 & 36.51 & 3.80 & 7.30 & 9.7 & 3.63 & 1.80 & 10.86 & 66.90 \\
\hline MEAN & & 605.6 & 172.8 & 221.5 & 1.23 & 44.60 & 4.03 & 10.62 & 11.84 & 3.74 & 1.78 & 10.70 & 66.59 \\
\hline $\mathrm{SD}$ & & 99.39 & 114.89 & 82.69 & 0.084 & 8.98 & 0.25 & 3.273 & 3.224 & 1.001 & 0.262 & 1.95 & 5.61 \\
\hline CV\% & & $16.41^{* *}$ & $66.49 * * *$ & $37.43^{* * *}$ & $6.78^{*}$ & $20.14^{*}$ & $6.22^{*}$ & $30.82^{* *}$ & $27.33^{* *}$ & $26.79 * *$ & $14.69^{*}$ & $18.27^{* *}$ & $111.50^{* * *}$ \\
\hline \multicolumn{14}{|l|}{ Asu River } \\
\hline A & $0-15$ & 889.6 & 92.8 & 17.6 & 1.32 & 333.8 & 3.85 & 7.66 & 19.80 & 6.07 & 1.23 & 15.52 & 83.15 \\
\hline C & $15-35$ & 669.6 & 292.8 & 37.6 & 1.48 & 352.6 & 3.42 & 5.21 & 12.10 & 5.06 & 1.00 & 12.16 & 83.49 \\
\hline $\mathrm{R}$ & 35 & & & & & & & & & & & & \\
\hline MEAN & & 779.6 & 192.8 & 27.6 & 1.40 & 343.2 & 3.64 & 6.43 & 15.95 & 5.56 & 1.12 & 13.80 & 83.32 \\
\hline SD & & 155.5 & 141.42 & 14.142 & 0.113 & 13.29 & 0.304 & 1.73 & 5.5 & 0.714 & 0.163 & 2.4 & 0.2404 \\
\hline CV\% & & $19.95^{* *}$ & $73.35^{\star * *}$ & $51.24^{* * *}$ & $8.08^{*}$ & $3.87^{*}$ & $8.37^{*}$ & $26.92^{* * *}$ & $34.14^{* *}$ & $12.83^{*}$ & $14.59^{*}$ & $17.17^{* *}$ & $0.29^{*}$ \\
\hline
\end{tabular}

$\mathrm{OC}=$ organic, $\mathrm{AVP}=$ available phosphorus, $\mathrm{TEA}=$ total exchangeable acidity, $\mathrm{BS}=$ base saturation, $\mathrm{CV}^{*}=$ low, ${ }^{* *}=$ moderate, ${ }^{* *}=$ high, $\mathrm{MC}=\mathrm{Moisture}$ content, BD: Bulk Density, ACEC $=$ Apparent cation exchange capacity, TEB $=$ total exchangeable bases.

(3.64) in soils derived from Asu river group to slightly acidic (4.20) in soils of coastal plain sand (SPDC, 2003) and had low variations $(<15 \%)$ in all soils studied. Organic carbon content of soils studied were low when compared with the critical level of $2 \%\left(20 \mathrm{~g} \cdot \mathrm{kg}^{-1}\right)$ reported by Chude et al. (2011) in Nigerian soils. This could be attributed to the prevalence of tropical conditions where the degradation of organic matter occurs at a faster rate, hence leaving less organic carbon in the soils (Nayak et al., 2002). Organic carbon exhibited low variations $(<15 \%)$ in coastal plain sand and moderate variation $(>15 \leq 35 \%)$ in soils of Asu 
river and Imo clay shale. Available phosphorus ranged from 7.47 - 15.95 $\mathrm{mg} \cdot \mathrm{kg}^{-1}$. Low available phosphorus obtained in the coastal plain sand and Imo clay shale could be attributed to the lower organic carbon contents, while the medium available phosphorus obtained in the soils of Asu river group could be attributed to the higher organic carbon content of these soils (FMANR, 1990).

Soil cation exchange capacity $(\mathrm{CEC})$ has been classified as low $\left(<6 \mathrm{Cmol}_{c}\right.$ $\left.\mathrm{kg}^{-1}\right)$, medium $\left(6-12 \mathrm{Cmol}_{\mathrm{c}} \mathrm{kg}^{-1}\right)$ and high $\left(>12 \mathrm{Cmol}_{\mathrm{c}} \mathrm{kg}^{-1}\right)$ for some Nigerian soils (Adepetu et al., 1979; Ojanuga and Awojuola, 1981). On the basis of this classification, mean CEC of Coastal plain sand soils (7.62) and Imo Clay shale (10.72) (Table 1) was within the medium class, while Asu River group was high (13.80). The coefficient of variation was high in coastal plain sand $(\mathrm{CV}=$ $44.11 \%)$ and moderate in Imo clay shale and Asu River group (CV $=18.27 \%)$ and $(\mathrm{CV}=17.17 \%)$, respectively.

\subsection{Organic Carbon Content under Forest Soils of the Different Parent Materials}

Figure 2 shows the mean soil organic carbon distribution and carbon sequestration under the three different Soil parent materials. The mean organic carbon content of the soils ranged from 6.14 to $10.62 \mathrm{~g} \cdot \mathrm{kg}^{-1}$ with the highest value obtained in soils underline by Imo clay shale. Results obtained from this study indicated that parent material had considerable influence on organic carbon content of soils. The mean carbon sequestration values ranged from 1575.35 $4676.41 \mathrm{~g} \cdot \mathrm{cm}^{-2}$. Imo clay shale had higher organic carbon content and carbon stock than the other parent materials (Figure 2). This may be attributed to the higher clay and organic carbon content of soils underline by Imo clay shale as clay has the ability to trap carbon. The results obtained from this study clearly indicated that parent material had an influence on organic carbon content and carbon and soil carbon sequestration.

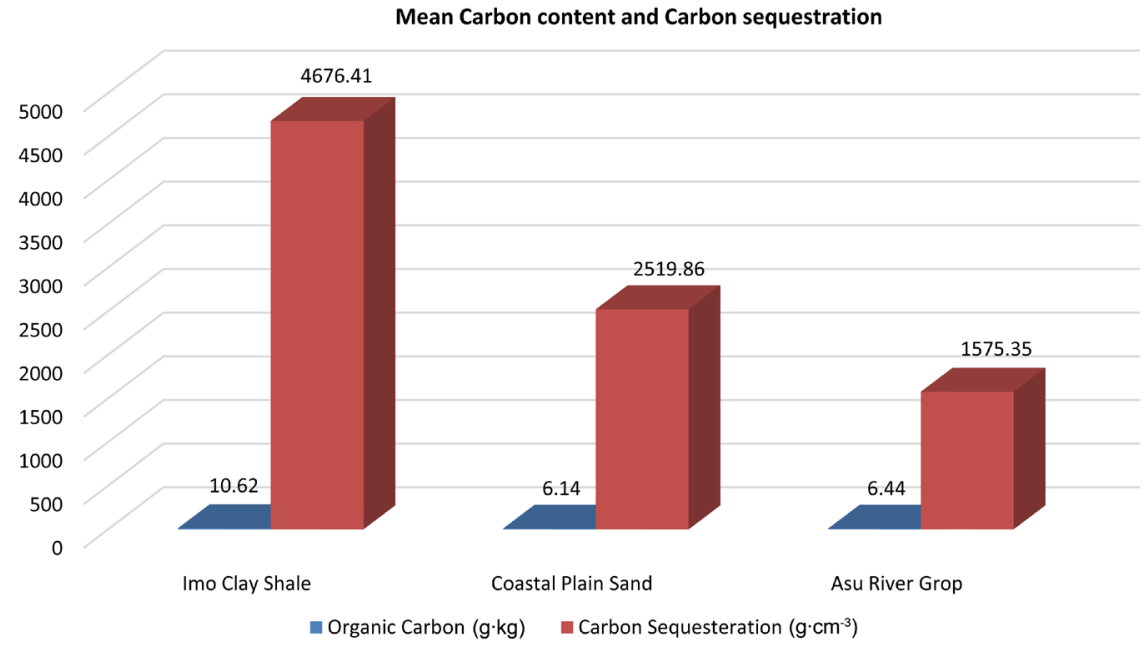

Figure 2. Mean carbon and carbon sequestration in soils underlain by different parent materials. 


\subsection{Effect of Soil Depth on Carbon Sequestration}

The effect of soil depth on carbon sequestration is shown in Table 2. Results revealed that sampling depth and horizon thickness had a remarkable influence on soil carbon sequestration as carbon sequestration increased with increase in profile depth (Table 2). As soil depth increased, horizon thickness equally increased and this influence the amount of carbon sequestered. Soils with deeper horizon thickness, sequestered more carbon than those in the upper horizon and this contradicts the findings of Ahukaemere et al. (2017) and Ahukaemere et al. (2020). In soils derived from coastal plain sand, $0-22 \mathrm{~cm}$ sampling depth sequestered the least carbon $\left(1474 \mathrm{~g} \cdot \mathrm{cm}^{-2}\right)$, while $100-180 \mathrm{~cm}$ sequestered the most carbon $\left(5468.16 \mathrm{~g} \cdot \mathrm{cm}^{-2}\right)$. In soils derived from Imo clay shale, $19-42 \mathrm{~cm}$ sampling depth sequestered the least carbon $\left(3473.92 \mathrm{~g} \cdot \mathrm{cm}^{-2}\right)$, while $82-133 \mathrm{~cm}$

Table 2. Effect of sampling depth on soil organic carbon sequestration.

\begin{tabular}{|c|c|c|c|}
\hline Depth $(\mathrm{cm})$ & $\mathrm{OC}\left(\mathrm{g} \cdot \mathrm{kg}^{-1}\right)$ & $\mathrm{CS}\left(\mathrm{g} \cdot \mathrm{cm}^{-3}\right)$ & CS: HT \\
\hline \multicolumn{4}{|c|}{ Coastal Plain Sand } \\
\hline $0-22(22)$ & 6.97 & 1474 & 67 \\
\hline $22-44(22)$ & 6.73 & 1495.41 & 67.97 \\
\hline $44-72(28)$ & 5.92 & 1955.97 & 69.86 \\
\hline $72-100(28)$ & 5.72 & 1985.98 & 70.93 \\
\hline $100-180(80)$ & 5.34 & 5468.16 & 68.35 \\
\hline Mean & 6.14 & 2475.90 & 68.82 \\
\hline SD & 0.68 & 1690.35 & 1.564 \\
\hline $\mathrm{CV}$ & 11.24 & 68.27 & 2.27 \\
\hline \multicolumn{4}{|l|}{ Imo Clay Shale } \\
\hline $0-19(19)$ & 15.20 & 3783.28 & 199.12 \\
\hline $19-42(23)$ & 12.80 & 3473.92 & 151.04 \\
\hline $42-82(40)$ & 9.20 & 4563.20 & 114.08 \\
\hline $82-133(50)$ & 8.60 & 5418 & 108.36 \\
\hline $133-180(47)$ & 7.30 & 4631.85 & 98.55 \\
\hline Mean & 10.62 & 4374.05 & 134.23 \\
\hline SD & 3.273 & 766.7 & 41.35 \\
\hline $\mathrm{CV}$ & 30.82 & 17.53 & 30.81 \\
\hline \multicolumn{4}{|c|}{ Asu River Group } \\
\hline $0-15(15)$ & 7.66 & 1516.68 & 101.12 \\
\hline $15-35(20)$ & 5.21 & 1542.16 & 77.11 \\
\hline Mean & 6.44 & 1529.42 & 89.11 \\
\hline SD & 1.73 & 18.01 & 16.9 \\
\hline $\mathrm{CV}$ & 26.92 & 1.2 & 19.1 \\
\hline
\end{tabular}

OC: Organic carbon, CS: Carbon sequestration, CS: HT: Ratio of Carbon sequestration, Horizon thickness. 
sequestered the most carbon $\left(5418 \mathrm{~g} \cdot \mathrm{cm}^{-2}\right)$. In soils derived from Asu river group sampling depth of $0-15 \mathrm{~cm}$ sequestered the least carbon $\left(1516.6 \mathrm{~g} \cdot \mathrm{cm}^{-2}\right)$, while depth of 15 - $35 \mathrm{~cm}$ sequestered the most carbon $\left(1542.16 \mathrm{~g} \cdot \mathrm{cm}^{-2}\right)$. Ahukaemere (2015) reported that deep soil profile allows more carbon accumulation than shallow depths. As long as horizon depth is higher, carbon sequestered will be high because horizon depth is among the functions of carbon sequestration calculation (Ahukaemere et al., 2017). The results of the coefficient of variation (\% CV) showed that carbon sequestered varied between low (1.20\%) in soils derived from Asu river group to high variation in soils derived from coastal plain sand (68.27\%) (Table 2). Ahukaemere (2015) observed that as sampling depth of soils increased, organic carbon storage also increased based on horizon thickness. The ratio of carbon sequestration to horizon thickness increase with the depth of soils in coastal plain sand except in the last horizon but decreased with depth in soils derived from Asu river group and Imo clay shale.

\section{Conclusion}

The results obtained from this study revealed that soil depth and horizon thickness as well as parent material influenced the amount of carbon sequestered in forest soils of South-eastern Nigeria. Forest soils underlain by Imo clay shale sequestered more carbon while those of Asu river group sequestered the least carbon. In soils underlain by coastal plain sand, carbon stock was dominated in the $100-180 \mathrm{~cm}$ depth, while in soils of Imo Clay shale; carbon stock was dominant in soil depth of the $82-133 \mathrm{~cm}$ layer and in soils derived from Asu river group carbon stock was highest in the depth of $15-35 \mathrm{~cm}$.

In conclusion, based on the results obtained, carbon is sequestered in subsurface horizons more than in soil surface horizons with greater thickness than in soil surface horizons. Organic carbon and horizons thickness also influence in carbon sequestered irrespective of parent materials. In order to maintain soil carbon sequestration, management practices that enhance depositions or retention of organic residues should be encouraged, while discouraging those that enhance soil nutrient loss.

\section{Conflicts of Interest}

The authors declare no conflicts of interest regarding the publication of this paper.

\section{References}

Adepetu, J. A., Adebayo, A. A., Aduayi, E. A., \& Alofe, G. O. (1979). A Preliminary Survey of the Fertility Status of Soils in Ondo State under Traditional Cultivation. Ife Journal of Agriculture, 1, 134-149.

Ahukaemere, C. M. (2015). Sequestration and Dynamics of Carbon and Nitrogen in Soils of Dissimilar Lithologies under Different Land Use Types in Southeastern Nigeria (266 p.). A PhD Thesis, Owerri: Department of Soil Science and Technology, Federal University of Technology. 
Ahukaemere, C. M., Okoli, N. H., Aririguzo, B. N., \& Onwudike, S. U. (2020). Tropical Soil Carbon Stocks in Relation to Fallow Age and Soil Depth. Malaysian Journal of Sustainable Agriculture (MJSA), 4, 5-9. https://doi.org/10.26480/mjsa.01.2020.05.09

Ahukaemere, M. C., Egbuche, C. T., Akamigbo, F. O. R., Onweremadu, E. U., Chukwuma, M. C., Uzoho, B. U., \& Ndukwu, B. N. (2017). Soil Carbon Sequestration Capacity Measurement per Centimetric Depth Unit: A Rational Approach. European Journal of Physical and Agricultural Sciences, 5, 40. http://www.idpublications.org

Alexander, P., Paustian, K., Smith, P., \& Moran, D. (2015). The Economics of Soil Carbon Sequestration and Agricultural Emissions Abatement. Soil, 1, 331-339. https://doi.org/10.5194/soil-1-331-2015

Aticho, A. (2013). Evaluating Organic Carbon Storage Capacity of Forest Soil: Case Study in Kafa Zone Bita District, Southwestern Ethiopia. American-Eurasian Journal of Agricultural \& Environmental Sciences, 13, 95-100.

Batjes, N. H. (1996). Total Carbon and Nitrogen in the Soils of the World. European Journal of Soil Science, 47, 151-163. https://doi.org/10.1111/j.1365-2389.1996.tb01386.x

Chris-Emenyonu, C. M., Onwudike, S. U., Akpan, I. W., Osisi, F. A., \& Okoli, N. H. (2019). Fertility Level of Some Degraded Soils of Imo State, Southeastern, Nigeria. The International Journal of Agriculture and Rural Development, 22, 4247-4259.

Chude, V. O., Malgwi, W. B., Ampu, I. Y., \& Ano, A. O. (2011). Manual on Soil Fertility Assessment (p. 102). Abuja: Federal Fertilizer Department in collaboration with $\mathrm{Na}-$ tional Programme for Food Security.

FAO (Food and Agricultural Organization) (2006). Guidelines for Soil Description (4th ed.). Rome.

FMANR (Federal Ministry of Agriculture and Natural Resources) (1990). Literature Review on Soil Fertility Investigation in Nigeria (281 p.). Ibadan: Bobma Publisher.

Gee, G. W., \& Or, D. (2002). Particle Size Distribution. In J. H. Dane, \& G. C. Topp (Eds.), Methods of Soil Analysis, Part 4. Physical Methods (pp. 255-293). Soil Science, Soc. Am Book Series No. 5, Madison, WI: ASA and SSSA.

Grossman, R. B., \& Reinsch, T. G. (2002). Bulk Density and Linear Extensibility. In J. H. Dane, \& G. C. Topp (Eds.), Methods of Soil Analysis, Part 4. Physical Methods (pp. 201-228). Soil Science, Soc. Am Book Series No. 5, Madison, WI: ASA and SSSA. https://doi.org/10.2136/sssabookser5.4.c9

Hendershot, W. H., Lalande, H., \& Duquette, M. (1993). Soil Reaction and Exchangeable Acidity. In M. R. Carter (Ed.), Soil Sampling and Methods of Soil Analysis (pp. 141-145). London: Lewis Publishers, Canadian Soc. Soil Science.

Lal, R. (2004). Soil Carbon Sequestration Impacts on Global Climate Change and Food Security. Science, 304, 1623-1627. https://www.c-agg.org/wp content/uploads/1623.pdf https://doi.org/10.1126/science.1097396

Landon, J. R. (1991). Booker Tropical Manual: A Handbook for Soil Survey and Agricultural Land Evaluation in the Tropic and Subtropics. New York: Longman Inc.

Nayak, D. C., Sarkar, D., \& Das, K. (2002). Forms and Distribution of Pedogenic Iron, Aluminium and Manganese in Some Benchmark Soils of West Bengal. Journal of the Indian Society of Soil Science, 50, 89-93.

Nelson, D. W., \& Sommers, L. E. (1996). Total Carbon, Organic Carbon and Organic Matter. In D. L. Sparks et al. (Eds.), Methods of Soil Analysis Part 3-Chemical Methods (pp. 961-1010). Soil Science Society of America. https://doi.org/10.2136/sssabookser5.3.c34

NIMET (Nigerian Meteorological Agency), Nigeria (2019). Climate Weather and Water 
Information, for Sustainable Development and Safety. Annual Climatic Report.

Ojanuga, A. G., \& Awojuola, A. I. (1981). Characteristics and Classification of the Soils of the Jos Plateau, Nigeria. Nigerian Journal of Soil Science, 10, 101-119.

Resck, D. V. S., Ferreira, E. A. B., Figueiredo, C. C., \& Zinn, Y. L. (2008). Dinâmica da matériaorgânica no Cerrado. In Fundamentos da matériaorgânica do solo: Ecossistemastropicais e subtropicais (2nd ed., pp. 359-417). Porto Alegre: Metrópole.

SAS Institute (2016). Statistical Analysis Software (SAS) User's Guide Version 9.4. Cary, NC: SAS Institute, Inc.

SPDC (Shell Petroleum Development Corporation) (2003). Environmental Monitoring for the Engineering Landfill Projects (p. 62). Final Report 2003.

Wilding, L. P. (1985). Spatial Variability: Documentation, Accommodation, and Implication to Soil Surveys. In D. R. Nielsen, \& J. Bouma (Eds.), Spatial Variability (pp. 166-194). Wageningen: Pudoc. 